NOTE

\title{
Transmission of the haplosporidian parasite MSX Haplosporidium nelsoni to the eastern oyster Crassostrea virginica in an upweller system
}

\author{
I. Sunilaa ${ }^{1, *}$, J. Karolus ${ }^{1}$, E. P. Lang ${ }^{2}$, M. E. Mroczka ${ }^{3}$, J. Volk ${ }^{1}$ \\ ${ }^{1}$ State of Connecticut, Department of Agriculture, Bureau of Aquaculture, Rogers Avenue, PO Box 97, Milford, Connecticut 06460, USA \\ ${ }^{2} 1$ Tower Hill Road, PO Box 314, Clinton, Connecticut 06413, USA \\ ${ }^{3}$ Cedar Island Marina Research Laboratory, Riverside Drive, PO Box 181, Clinton, Connecticut 06413, USA
}

\begin{abstract}
The haplosporidian oyster parasite MSX (Multinucleated Sphere X) Haplosporidium nelsoni was transmitted to eastern oysters Crassostrea virginica. Hatchery-raised, MSX-free juvenile oysters were placed in upweller tanks. Water to the tanks was filtered through a screen with $1 \mathrm{~mm}^{2}$ openings and originated from the water column overlaying naturally infected oysters beds (MSX prevalence 17 to $57 \%$ ). MSX was diagnosed by histopathological analysis. MSXdisease (57\% prevalence) with increased mortality (19\%) was observed 11 wk after the beginning of the exposure and mortality of $80 \%$ after $16 \mathrm{wk}$. The study demonstrates transmission of MSX via water-borne infectious agents capable of passing through a $1 \mathrm{~mm}$ filter.
\end{abstract}

KEY WORDS: Haplosporidium nelsoni · Transmission · Crassostrea virginica

Resale or republication not permitted without written consent of the publisher

MSX (Multinucleated Sphere X) disease is caused by the haplosporidian parasite Haplosporidium nelsoni. It has caused massive mortalities in Delaware Bay since 1957 and in Chesapeake Bay since 1959 (Haskin et al. 1966, Andrews \& Wood 1967). MSX was described in Long Island Sound, Connecticut, in 1960 (Haskin \& Andrews 1988), but it had not been causing major epizootics in that area until autumn 1997 (Sunila et al. 1999). The infective stage has not been recognized, but Farley (1967) suggested a uninucleated, infective sporoplasm escaping from the spore. Since sporulation is extremely rare and, therefore, cannot sustain widespead infection, an alternate host has been suggested (Andrews 1968, Haskin \& Andrews 1988). Several efforts have been made to transmit MSX to oysters under controlled situations. Canzonier (1974) implanted in-

*E-mail: dept.agric@snet.net fected tissue into uninfected recipients without evidence of transmission. He also reported failure to transmit into uninfected recipients by proximity to infected oysters or suspected alternate hosts; feeding with infected material both forced and as a suspension in the aquarium water; and inoculation into muscle, heart, visceral mass and mantle tissue (Canzonier 1968). Attempts to transmit infections by using spores were unsuccessful whether the spores were fed to oysters held in aquaria or inoculated into the mantle cavity of oysters (Andrews 1979). Field experiments conducted by Andrews (1968) in Chesapeake Bay, Virginia, demonstrated that uninfected, susceptible oysters acquire infection when imported to epizootic areas. Information about infection rates in juvenile oysters is rare. Myhre \& Haskin (1969) reported high MSX prevalences in hatchery-raised oyster spat imported to enzootic waters in Delaware Bay. According to our knowledge, the present paper is the first report of transmission of MSX to oysters in an upweller system.

Materials and methods. The upweller system was situated on a wharf in Clinton Harbor, Connecticut, on Long Island Sound. Hatchery-raised, MSX-free, MSXsusceptible oysters ( 300000 , size $4 \mathrm{~mm}$ ) were received from a Long Island south shore hatchery. The hatchery receives water from a salt water well and is situated in an area where MSX has not been detected. The oyster nursery system consisted of 5 tanks arranged into 1 upweller and 4 raceways. Oysters were held in the upweller system until they reached $1.3 \mathrm{~cm}$, at which point in time they were transferred to the raceway system. The upweller system consisted of 14 silos (diameter $38 \mathrm{~cm}$ ) with a $1 \mathrm{~mm}$ bottom mesh. Incoming water was filtered from the harbor. The intake tubes with $4.8 \mathrm{~mm}$ screens in the ends were situated $30 \mathrm{~cm}$ above the 
bottom at a depth of 1.5 (low tide) to $3.4 \mathrm{~m}$ (high tide). Water was pumped through the silos at a flow rate of $191 \mathrm{~min}^{-1}$. During the experiment, water temperature varied from 15 to $26^{\circ} \mathrm{C}$ and salinity from 16 to $28 \%$. Five samples were taken for histopathology: juvenile oysters directly from the hatchery, a sample from the tanks in the beginning of mortality (size $21.1 \mathrm{~mm}, \mathrm{SD} 3.1$ ), and 3 samples from the oyster beds surrounding the intake tube during the peak mortality in the upweller system. The first sample was obtained from Cedar Island oyster beds (size $103.7 \mathrm{~mm}$, SD 15.3, $100 \mathrm{~m}$ south of the intake tube), the second from Hammock River (size $97.3 \mathrm{~mm}$, SD 16.9, $550 \mathrm{~m}$ east of the intake tube) and the third from Hammonasset River (size $101.0 \mathrm{~mm}$, SD 21.6, $640 \mathrm{~m}$ west of the intake tube). Thirty specimens of each group were fixed in Davidson's fixative (in 20\% artificial seawater), and $6 \mu \mathrm{m}$ paraffin sections were stained with hematoxylin-eosin. Advanced MSX cases were stained also with Ziehl and Harris' hematoxylin for detecting acid-fast spores according to Farley (1965). MSX infections were classified as initial, intermediate, advanced or terminal according to Farley (1968). Perkinsus marinus infections were detected and the intensity of the infections rated using the Mackin scale according to Ray (1954). Mortality was estimated by the box-count method using 100 live oysters or articulated shells (Smith \& Jordan 1992).

Results and discussion. Hatchery-raised juvenile oysters were not infected with MSX before they were imported to Connecticut. After $11 \mathrm{wk}$ of exposure in tanks to filtered water from naturally infected oyster beds, prevalence of MSX was $57 \%$ and mortality was $19 \%$. There were 8 oysters with initial infections (infection limited to gill epithelium, Fig. 1A), 4 intermediate cases (involvement of the digestive diverticula as well as the gill epithelium) and 5 advanced cases (plasmodia throughout the tissues, Fig. 1B). Coinfections were found with Perkinsus marinus in $23 \%$ of the oysters (7/30, weighted prevalence 0.6 , very light infection) and with Nematopsis ostrearum in $40 \%$ of the oysters. The ciliate Stegotricha sp. was found in the digestive diverticula of $7 \%$ of the oysters and other species from the family Ancistrocomidae were found on the gills of $30 \%$ of the oysters. Hemocyte response in MSX-infected specimens was light or absent. The first field sample (Cedar Island) had a $57 \%$ prevalence of MSX consisting of 1 with an initial infection, 4 with intermediate infections, 8 with advanced infections and 4 with terminal infections (profuse parasitemia in all tissues). Coinfections were as follows: $P$. marinus, $100 \%$ (weighted prevalence 2.1, light to moderate infection); N. ostrearum, $87 \%$; Stegotricha sp., 27\% in the digestive diverticulum; and other species from the family Ancistrocomidae on the gills, 20\%. The second field sample (Hammock River) had a $50 \%$ prevalence of MSX: 2 with initial infections, 2 with intermediate infections, 7 with advanced infections and 4 with terminal infections. Coinfections were as follows: P. marinus, $90 \%$ (weighted prevalence 1.1, light infection); $N$. ostrearum, $100 \%$; Stegotricha sp., $13 \%$ in the digestive
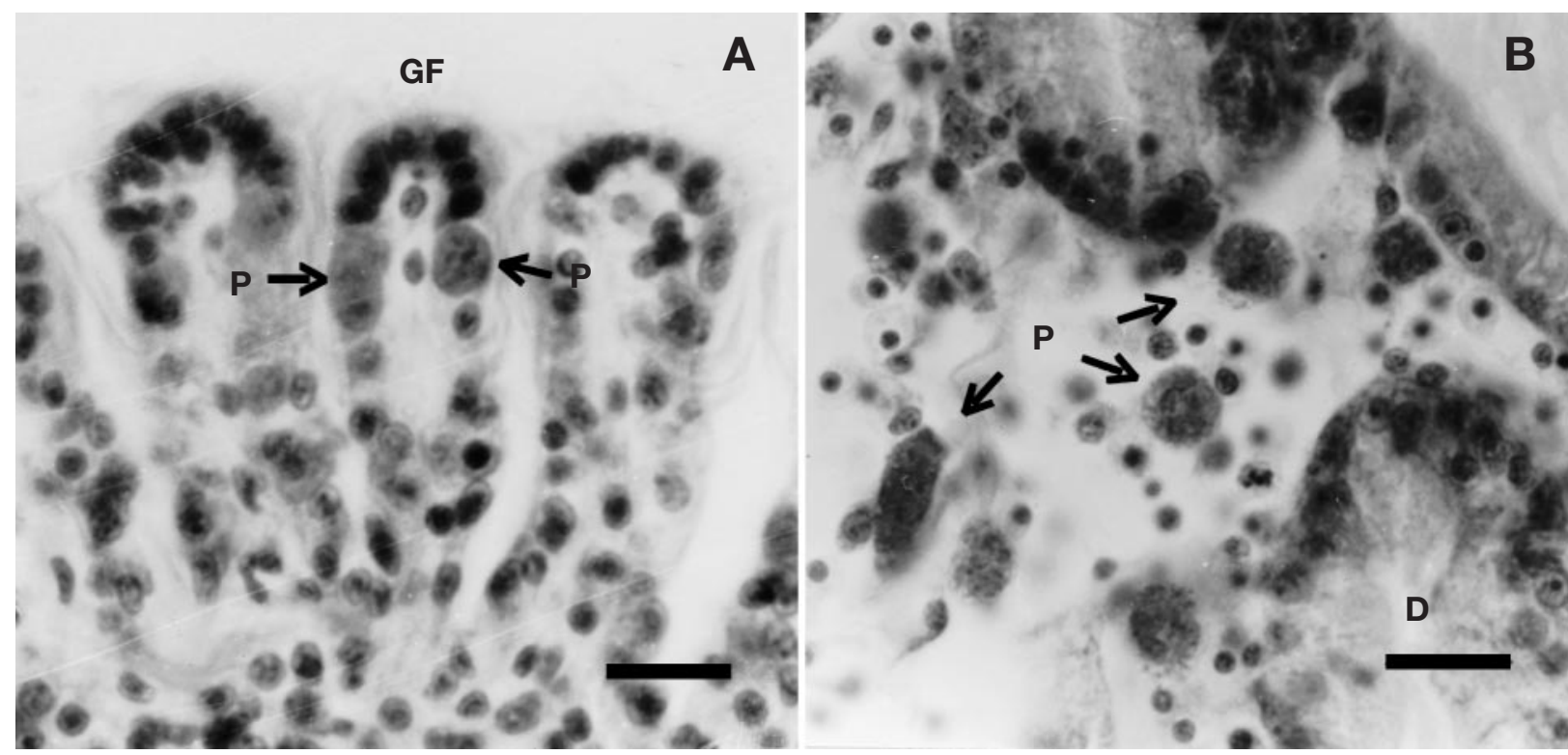

Fig. 1. MSX infection Haplosporidium nelsoni transmitted to hatchery-raised, disease-free eastern oysters Crassostrea virginica. H\&E stained paraffin sections. (A) Initial infection. H. nelsoni plasmodia in the gills. P: plasmodia; GF: gill filament. Scale bar $=20 \mu \mathrm{m}$. (B) Advanced infection. Several H. nelsoni plasmodia in the digestive diverticula. P: plasmodia; D: digestive tubule. Scale bar $=20 \mu \mathrm{m}$ 
diverticula and epibranchial chamber; and other species from the family Ancistrocomidae, $20 \%$ on the gills. The third field sample (Hammonasset River) had a $17 \%$ prevalence of MSX: 1 with an intermediate infection, 3 with advanced infections and 1 with a terminal infection. The following coinfections were observed: P. marinus, 97\% (weighted prevalence 1.4, light infection); N. ostrearum, 100\%; Stegotricha sp., $33 \%$ in the digestive diverticula; and other species from the family Ancistrocomidae, $40 \%$ on the gills, palps or mantle. Polydora websteri was present in the shells of each field sample $(100 \%)$. The experimental sample had $80 \%$ mortality by the end of October (4 mo after the beginning of the exposure). The Cedar Island field sample experienced $83 \%$ mortality during the autumn with $85 \%$ mortality of spat from summer 1997.

Typical observations for initial infection stages in the gills described in this paper are supported by earlier observations (Farley 1967, 1968, Ford 1985), which strongly suggests a water-borne infectious stage. In the earliest infections, MSX plasmodia were found outside the basement membranes of the gill epithelia and between the epithelial cells in oysters collected from upwellers (Fig. 1A). The samples were put in the tanks during 'prime infection period' (late May to mid-July), as defined by Andrews (1979).

New infections in this study most likely originate from water-borne infectious particles, but direct transmission via spores from oysters is unlikely because of the absence of spores in the field samples of oyster populations in the vicinity of the intake tube. Infectious stages may have been delivered directly by an alternate host, small enough to pass the $1 \mathrm{~mm}$ screen, or released by the alternate host in the field. Several species of macro-organisms were entrained in the upweller-raceway system during the experiment: fish such as Menidia menidia, Syngnathus fuscus and Fundulus sp. and invertebrates such as Crangon septemspinosa, Paleomonetes vulgaris, Neomysis americana, Carcinus maenas, Nereis succinea, Balanus sp., Ilyanassa obsoleta, Crepidula plana, Crepidula fornicata, Molgula manhattensis and natural set of Crassostrea virginica. These organisms entered through the filters, survived their trip through the pump and were able to live in the tanks for $2 \mathrm{wk}$ periods between tank cleanings. Earlier failures to transmit the disease with proximity to infected oysters in the laboratory (Canzonier 1974), and the results of this study suggest the involve-

Editorial responsibility: Albert Sparks,

Seattle, Washington, USA ment of an alternate host, because our test arrangement did not exclude any of the biodiversity from the water column and selected only according to size. The alternate host most likely was not one of the estuarine species excluded by the filters. In future studies designed to identify the alternate host, one could focus on the species entrained in the upweller-raceway system.

\section{LITERATURE CITED}

Andrews JD (1968) Oyster mortality studies in Virginia. VII. Review of epizootiology and origin of Minchinia nelsoni. Proc Natl Shellfish Assoc 58:23-36

Andrews JD (1979) Oyster diseases in Chesapeake Bay. Mar Fish Rev 41:45-53

Andrews JD, Wood JL (1967) Oyster mortality studies in Virginia. VI. History and distribution of Minchinia nelsoni, a pathogen of oysters, in Virginia. Chesapeake Sci 8:1-13

Canzonier WJ (1968) Present status of attemps to transmit Minchinia nelsoni under controlled conditions. Proc Natl Shellfish Assoc 58:1

Canzonier WJ (1974) Tissue grafts in the American oyster, Crassostrea virginica. Proc Natl Shellfish Assoc 64:92-101

Farley CA (1965) Acid-fast staining of haplosporidian spores in relation to oyster pathology. J Invertebr Pathol 7: $144-147$

Farley CA (1967) A proposed life cycle of Minchinia nelsoni (Haplosporida, Haplosporidiidae) in the American oyster Crassostrea virginica. J Protozool 14:616-625

Farley CA (1968) Minchinia nelsoni (Haplosporida) disease syndrome in the American oyster Crassostrea virginica. J Protozool 15:585-599

Ford SE (1985) Chronic infections of Haplosporidium nelsoni (MSX) in the oyster Crassostrea virginica. J Invertebr Pathol 45:94-107

Haskin HH, Andrews JD (1988) Uncertainties and speculations about the life cycle of the eastern oyster pathogen Haplosporidium nelsoni (MSX). Am Fish Soc Spec Publ 18:5-22

Haskin HH, Stauber LA, Mackin JA (1966) Minchinia nelsoni n. sp. (Haplosporida, Haplosporidiidae): causative agent of the Delaware Bay oyster epizootic. Science 153: $1414-1416$

Myhre JL, Haskin HH (1969) MSX-prevalence in various stocks of laboratory-reared oyster spat. Proc Natl Shellfish Assoc 59:7

Ray SM (1954) Biological studies of Dermocystidium marinum, a fungus parasite of oysters. The Rice Institute Pamphlet, Spec Iss. Rice Institute, Houston, TX, p 1-114

Smith GF, Jordan SJ (1992) Monitoring Maryland's Chesapeake Bay oysters. Chesapeake Bay Research and Monitoring Division CBRM-OX-93-3, Oxford, MD, p 1-93

Sunila I, Karolus J, Volk J (1999) A new epizootic of Haplosporidium nelsoni (MSX), a haplosporidian oyster parasite, in Long Island Sound, Connecticut. J Shellfish Res 18:169-174

Submitted: December 12, 1998; Accepted: March 22, 2000 Proofs received from author(s): August 1, 2000 